\title{
Phase Formation, Microstructure and Permeability of Fe-Deficient Ni-Cu-Zn Ferrites, (I): Effect of Sintering Temperature
}

\author{
Christoph Priese and Jörg Töpfer * (D) \\ Dept. SciTec., Ernst-Abbe-Hochschule Jena, 07745 Jena, Germany; christoph.priese@eah-jena.de \\ * Correspondence: Joerg.Toepfer@eah-jena.de; Tel.: +49-3641-205-479
}

Citation: Priese, C.; Töpfer, J. Phase Formation, Microstructure and Permeability of Fe-Deficient Ni-Cu-Zn Ferrites, (I): Effect of Sintering Temperature. Magnetochemistry 2021, 7, 118. https://doi.org/10.3390/ magnetochemistry7080118

Academic Editor: Vasiliki Tsakaloudi

Received: 5 July 2021

Accepted: 9 August 2021

Published: 14 August 2021

Publisher's Note: MDPI stays neutral with regard to jurisdictional claims in published maps and institutional affiliations.

Copyright: (c) 2021 by the authors. Licensee MDPI, Basel, Switzerland. This article is an open access article distributed under the terms and conditions of the Creative Commons Attribution (CC BY) license (https:// creativecommons.org/licenses/by/ $4.0 /)$.

\begin{abstract}
We have studied the densification, phase formation, microstructure, and permeability of stoichiometric and Fe-deficient $\mathrm{Ni}-\mathrm{Cu}-\mathrm{Zn}$ ferrites of composition $\mathrm{Ni}_{0.30} \mathrm{Cu}_{0.20} \mathrm{Zn}_{0.50+\mathrm{z}} \mathrm{Fe}_{2-\mathrm{z}} \mathrm{O}_{4-(\mathrm{z} / 2)}$ with $0 \leq \mathrm{z} \leq 0.06$ sintered at temperatures from $900{ }^{\circ} \mathrm{C}$ to $1150{ }^{\circ} \mathrm{C}$. The shrinkage is shifted from $1000{ }^{\circ} \mathrm{C}$ for $\mathrm{z}=0$ towards lower temperatures and reaches its maximum rate at $900{ }^{\circ} \mathrm{C}$ for $\mathrm{z}=0.02$. Stoichiometric ferrites show regular growth of single-phase ferrite grains if sintered at $T_{\mathrm{S}} \leq 1100^{\circ} \mathrm{C}$. Sintering at $1150{ }^{\circ} \mathrm{C}$ leads to the formation of a small amount of $\mathrm{Cu}_{2} \mathrm{O}$, triggering exaggerated grain growth. Fe-deficient compositions $(\mathrm{z}>0)$ form $\mathrm{Cu}$-poor stoichiometric ferrites coexisting with a minority $\mathrm{CuO}$ phase after sintering at $900-1000{ }^{\circ} \mathrm{C}$. At $T_{\mathrm{s}} \geq 1050{ }^{\circ} \mathrm{C}, \mathrm{CuO}$ transforms into $\mathrm{Cu}_{2} \mathrm{O}$, and exaggerated grain growth is observed. The formation of $\mathrm{Cu}$ oxide second phases is investigated using XRD, SEM, and EDX. The permeability of the ferrites increases with sintering temperature up to a maximum permeability of $\mu=230$ for $\mathrm{z}=0$ or $\mu=580$ for $\mathrm{z}=0.02$, respectively, at $T_{\mathrm{s}}=1000^{\circ} \mathrm{C}$. At higher sintering temperatures, the permeability decreases, which is due to the formation of a microstructure with intra-crystalline porosity in large grains, and a non-magnetic $\mathrm{Cu}$ oxide grain boundary phase.
\end{abstract}

Keywords: soft ferrites; magnetic permeability; polycrystalline microstructure

\section{Introduction}

$\mathrm{Ni}-\mathrm{Cu}-\mathrm{Zn}$ ferrites are an important group of soft magnetic materials for many applications including power ferrites, EMI devices, and multilayer inductors. The main advantages of $\mathrm{Ni}-\mathrm{Cu}-\mathrm{Zn}$ ferrites are their low sintering temperature $T_{\mathrm{s}}$, high resistivity, medium permeability, low loss, and good performance up to $\mathrm{MHz}$ frequencies [1-4]. Magnetic properties critically depend, among other factors, on ferrite composition and microstructure. Owing to the lower sintering temperatures of $\mathrm{Ni}-\mathrm{Cu}-\mathrm{Zn}$ ferrites as compared with $\mathrm{Ni}-\mathrm{Zn}$ or $\mathrm{Mn}-\mathrm{Zn}$ ferrites, it is necessary to investigate in detail the effect of sintering conditions on the microstructure and magnetic properties of the ferrites, and to design specific sintering protocols to achieve optimum performance. Many studies were performed to investigate the low-temperature sintering behavior of $\mathrm{Ni}-\mathrm{Cu}$-Zn ferrites. For applications in multilayer inductors, ferrites are cofired with silver metallization as low as $T_{\mathrm{s}} \leq 900{ }^{\circ} \mathrm{C}$. Most studies report on a specific ferrite composition, which is fired at $900{ }^{\circ} \mathrm{C}$ using a sintering additive, as well as its microstructure formation, permeability, and DC bias superposition behavior [5-8]. Papers reporting correlations between Ni-Cu-Zn ferrite composition, sintering behavior, and magnetic properties, on the other hand, are scarce $[9,10]$. A common feature of low-firing ferrite compositions is a small deficiency of iron oxide in the starting oxide mixture $\left(<50 \mathrm{~mol} \% \mathrm{Fe}_{2} \mathrm{O}_{3}\right)$. Such Fe-deficient compositions typically translate into a spinel formula with less than two Fe per formula unit, for example, $\mathrm{Me}_{1.02} \mathrm{Fe}_{1.98} \mathrm{O}_{3.99}$, as compared with stoichiometric ferrites with $50 \mathrm{~mol} \% \mathrm{Fe}_{2} \mathrm{O}_{3}$ and the formula unit $\mathrm{MeFe}_{2} \mathrm{O}_{4}$. It has been reported that Fe-deficiency enhances densification [11-14]. Moreover, it has was found that secondary phases might precipitate at grain boundaries and affect the magnetic properties. In Fe-deficient ferrites, tenorite $\mathrm{CuO}$ was found to form at triple points or grain boundaries 
after sintering at $900{ }^{\circ} \mathrm{C}$ [14] and at $1100{ }^{\circ} \mathrm{C}$ [15]. The formation of microstructural defects including precipitates of copper at grain boundaries was also observed in Fe-deficient $\mathrm{Ni}-\mathrm{Cu}-\mathrm{Zn}$ ferrites using TEM [16]. On the other hand, Sun et al. reported the formation of $\mathrm{ZnO}$ as secondary phase in Fe-deficient samples [17]. For a stoichiometric Ni-Cu-Zn ferrite, a detailed study of phase composition and microstructure revealed precipitation of $\mathrm{CuO}$ and $\mathrm{ZnO}$ after sintering at $1200{ }^{\circ} \mathrm{C}$, with their concentrations depending on green density, sintering temperature, and cooling rate [18,19]. Nazrin et al. [20] did not detect any secondary phases in Fe-deficient ferrites.

In this contribution, we report a systematic study on phase formation, microstructure, and permeability of Fe-deficient $\mathrm{Ni}_{0.30} \mathrm{Cu}_{0.20} \mathrm{Zn}_{0.50+\mathrm{z}} \mathrm{Fe}_{2-\mathrm{z}} \mathrm{O}_{4-(\mathrm{z} / 2)}$ ferrites with $0 \leq \mathrm{z} \leq 0.06$. In part I of this study, we focus on the effect of sintering temperature in air atmosphere. In part II, we will describe in detail the effect of oxygen partial pressure. It is found that the grain size increases with sintering temperature $T_{\mathrm{S}}$ until a critical temperature, where intra-crystalline pores and abnormally grown large grains start to appear. For $\mathrm{z} \geq 0, \mathrm{CuO}$ precipitates at grain boundaries, which is transformed into $\mathrm{Cu}_{2} \mathrm{O}$ at high temperature. The amount of $\mathrm{CuO}$ increases with Fe-deficiency $\mathrm{z}$. The permeability increases with $T_{\mathrm{s}}$ and grain size in the range of predominance of regular grain growth. At higher $T_{\mathrm{s}}$, the formation of $\mathrm{Cu}_{2} \mathrm{O}$ at grain boundaries initiates abnormal grain growth and intra-crystalline porosity and, consequently, a decrease in permeability is observed.

\section{Results}

\subsection{Powder Properties}

Single-phase ferrite powders were obtained after calcination at $900{ }^{\circ} \mathrm{C}(\mathrm{XRD}$ results not shown here). After milling, a mean particle size of the powder of $d_{50}=0.7 \mu \mathrm{m}$ was measured using laser diffraction, which represents the size of aggregates. The specific surface of the ferrite powder of $S=5 \mathrm{~m}^{2} / \mathrm{g}$ corresponds to a mean particle diameter of primary particles of $d_{\mathrm{BET}}=220 \mathrm{~nm}$.

\subsection{Shrinkage and Densification Behavior}

Dilatometric shrinkage measurements of pellets made from milled powders demonstrate that the Fe-deficiency $\mathrm{z}$ significantly affects the shrinkage and shrinkage rate in $\mathrm{Ni}_{0.30} \mathrm{Cu}_{0.20} \mathrm{Zn}_{0.50+\mathrm{z}} \mathrm{Fe}_{2-\mathrm{z}} \mathrm{O}_{4-(\mathrm{z} / 2)}$ (Figure 1a).

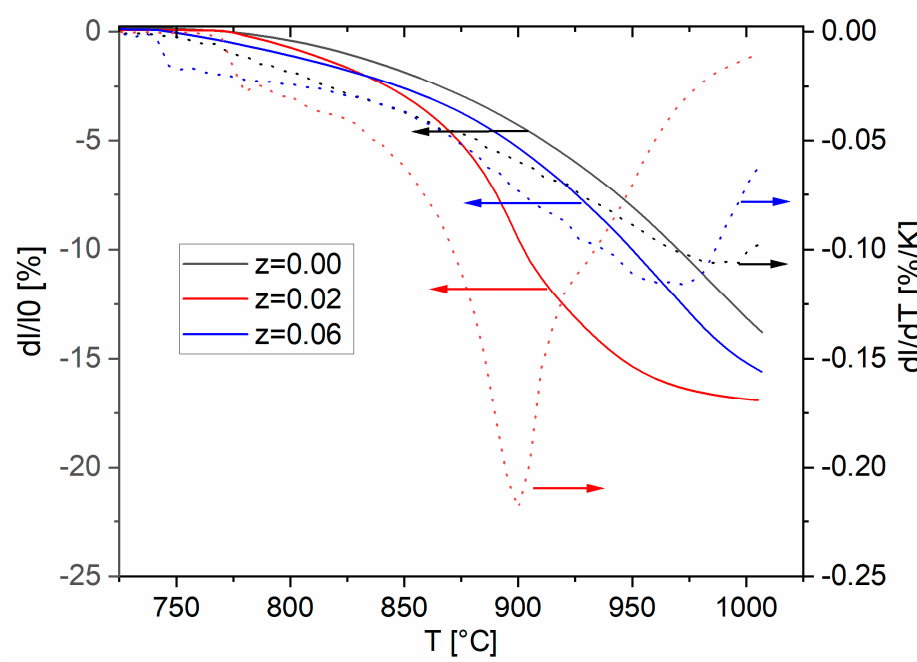

(a)

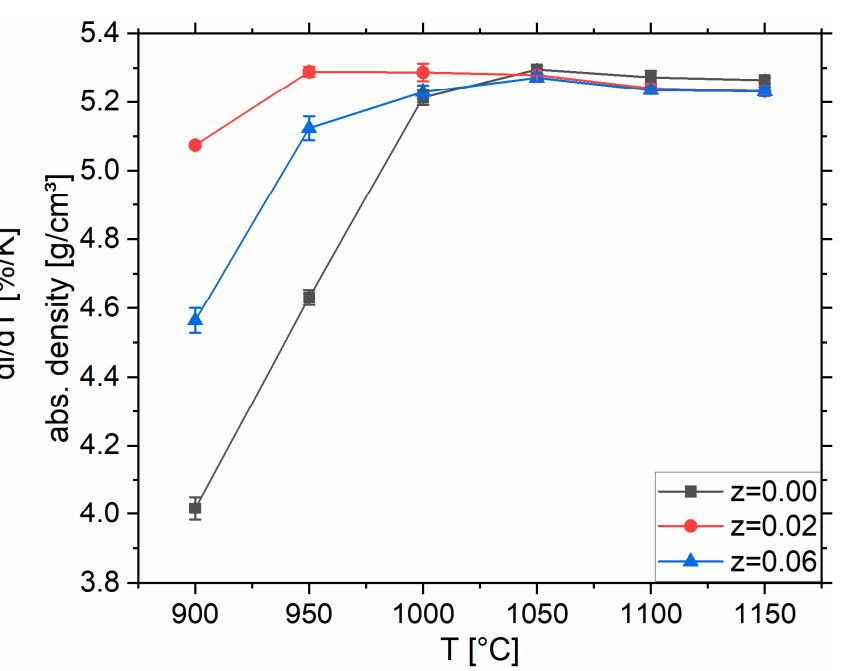

(b)

Figure 1. (a) Relative shrinkage and shrinkage rate vs. temperature and (b) absolute density vs. sintering temperature for $0 \leq \mathrm{z} \leq 0.06$.

Stoichiometric $\mathrm{Ni}_{0.3} \mathrm{Cu}_{0.2} \mathrm{Zn}_{0.5} \mathrm{Fe}_{2} \mathrm{O}_{4}(\mathrm{z}=0)$ has its maximum shrinkage rate at about $970{ }^{\circ} \mathrm{C}$. Shrinkage is shifted towards lower temperatures with increasing Fe-deficiency; 
for $\mathrm{z}=0.02$, the maximum shrinkage is at $900{ }^{\circ} \mathrm{C}$. For $\mathrm{z}>0.02$, the temperature of the maximum shrinkage rate is increased (Figure 1a). The observed differences in the shrinkage of stoichiometric and Fe-deficient $\mathrm{Ni}-\mathrm{Cu}-\mathrm{Zn}$ ferrites are also reflected in the densification behavior. Stoichiometric Ni-Cu-Zn ferrite $(z=0)$ experiences limited densification at $900{ }^{\circ} \mathrm{C}$ $(75 \%)$ and sintering at $T_{\mathrm{s}} \geq 1000{ }^{\circ} \mathrm{C}$ is required for densification (Figure $1 \mathrm{~b}$ ). Ferrites with $\mathrm{Z}=0.02$ exhibit excellent densification behavior and sintering at $900{ }^{\circ} \mathrm{C}$ already leads to good density of $5.07(1) \mathrm{g} / \mathrm{cm}^{3}(95 \%)$; sintering at $T \geq 950{ }^{\circ} \mathrm{C}$ results in almost complete densification of $5.28(1) \mathrm{g} / \mathrm{cm}^{3}(99 \%)$. For larger Fe-deficiency $(\mathrm{z}=0.06)$, a somewhat reduced densification is observed and a sintering temperature of $T_{\mathrm{s}}=1000^{\circ} \mathrm{C}$ is necessary to achieve good densities.

\subsection{Microstructure and Element Distribution}

SEM micrographs of samples with different values of Fe-deficiency z sintered at temperatures between $900{ }^{\circ} \mathrm{C}$ and $1150{ }^{\circ} \mathrm{C}$ are presented in Figure 2 . The stoichiometric ferrite $(\mathrm{z}=0.00)$ exhibits regular grain growth up to $T_{\mathrm{S}} \leq 1100^{\circ} \mathrm{C}$, whereas a sample sintered at $1150{ }^{\circ} \mathrm{C}$ consists of very large grains of about $1 \mathrm{~mm}$ in size as a result of exaggerated grain growth. For samples sintered at $T_{\mathrm{s}} \geq 1050{ }^{\circ} \mathrm{C}$, intra-crystalline porosity is observed.

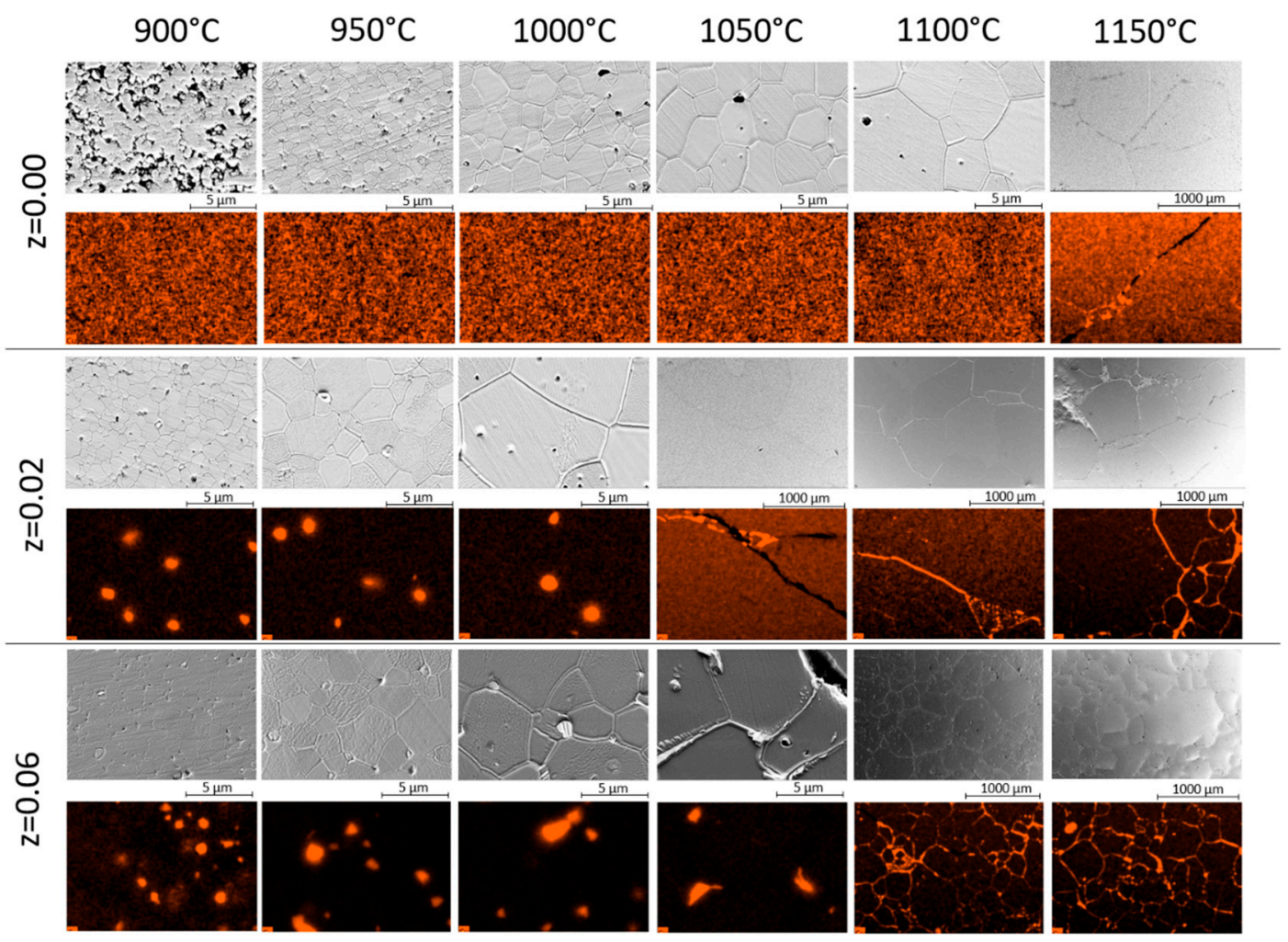

Figure 2. Microstructure images (SEM, SE mode) and EDX mapping of Cu-distribution in dependence of sintering temperature for $\mathrm{z}=0.00,0.02$, and 0.06 (representative examples; SEM and EDX not from the same sample area).

The evolution of grain size versus temperature (Figure 3) confirms regular grain growth behavior for $T_{\mathrm{s}}<1150{ }^{\circ} \mathrm{C}$.

For Fe-deficient ferrites $(\mathrm{z}>0)$, exaggerated grain growth already starts to appear at lower temperatures, at $T_{\mathrm{S}}>1000{ }^{\circ} \mathrm{C}$ for $\mathrm{z}=0.02$ and at $T_{\mathrm{S}}>1050{ }^{\circ} \mathrm{C}$ for $\mathrm{z}=0.06$ (Figures 2 and 3). Pores within the ferrite grains were found at $T_{\mathrm{S}}=1000{ }^{\circ} \mathrm{C}$ for $\mathrm{z}=0.02$ and at $T_{\mathrm{S}}=1050{ }^{\circ} \mathrm{C}$ for $\mathrm{z}=0.06$, i.e., at temperatures about $50{ }^{\circ} \mathrm{C}$ below the beginning of exaggerated grain growth.

The composition of the matrix grains and grain boundary regions was studied using energy dispersive X-ray analysis (EDX). The composition of the ferrite matrix grains 
remains unchanged (within the given resolution) for different sintering temperatures, as demonstrated for $\mathrm{z}=0.02$ in Figure $4 \mathrm{a}$.

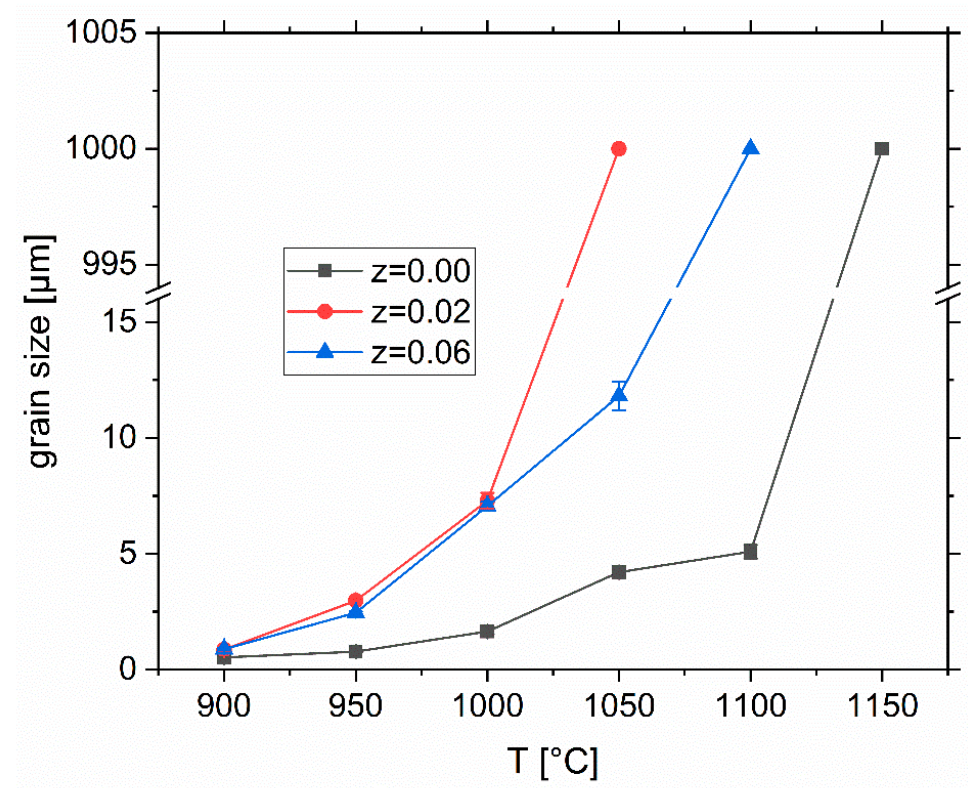

Figure 3. Ferrite grain size vs. sintering temperature for $0 \leq \mathrm{z} \leq 0.06$.

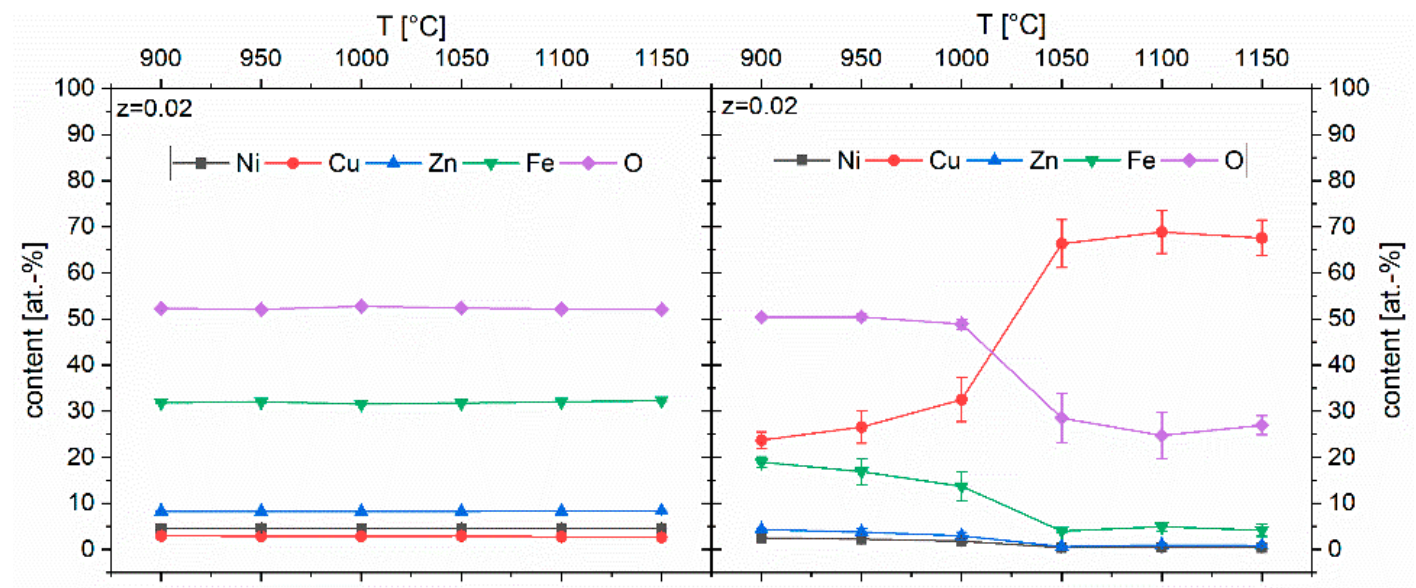

(a)

(c)

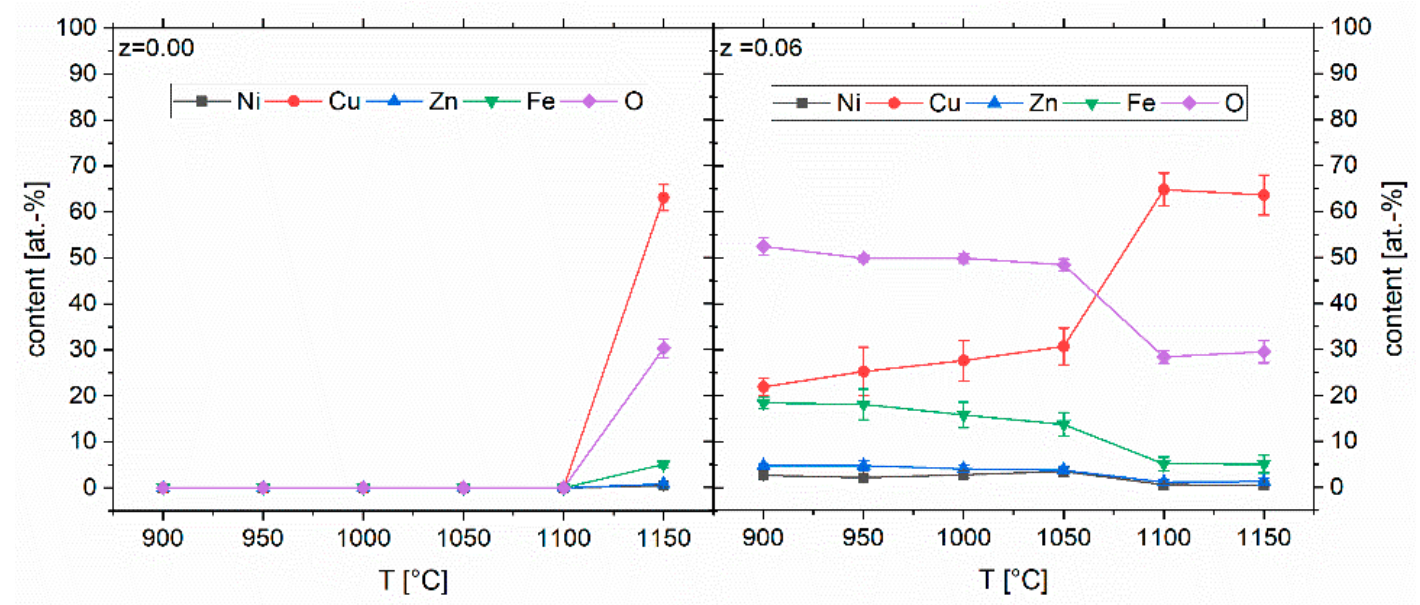

(b)

(d)

Figure 4. Chemical composition determined using EDX point scans vs. sintering temperature of (a) ferrite matrix grains $(\mathrm{z}=0.02)$ and triple points or grain boundary regions for $(\mathbf{b}) \mathrm{z}=0.00,(\mathbf{c}) \mathrm{z}=0.02$, and $(\mathbf{d}) \mathrm{z}=0.06$ 
The distribution of the copper oxide phase in the microstructure was studied in some detail. In addition to SEM micrographs, Figure 2 shows EDX mappings of the $\mathrm{Cu}$ distribution for all samples and sintering temperatures $T_{\mathrm{s}}$. In the case of stochiometric ferrites $(\mathrm{z}=0)$, a homogeneous distribution of $\mathrm{Cu}$ is found, except for the sample sintered at $1150{ }^{\circ} \mathrm{C}$, where enrichment of $\mathrm{Cu}$ is detected at grain boundaries between very large grains.

For Fe-deficient ferrites ( $\mathrm{z}=0.02$ and 0.06 ), $\mathrm{Cu}$-rich regions in the triple points between regularly grown ferrite grains are found. A different situation is observed in microstructures dominated by accelerated grain growth. At $T_{\mathrm{s}} \geq 1050{ }^{\circ} \mathrm{C}$ for $\mathrm{z}=0.02$ and at $T_{\mathrm{s}} \geq 1100{ }^{\circ} \mathrm{C}$ for $\mathrm{z}=0.06$, the $\mathrm{Cu}$ oxide phase is found to form a network along the grain boundaries of the very large ferrite grains (Figure 2). The variation of the elemental concentrations of copper and oxygen from EDX measurements is depicted versus sintering temperature in Figure $4 \mathrm{~b}-\mathrm{d}$. For $\mathrm{z}=0$, a separate copper oxide phase with $63.1 \mathrm{at} \% \mathrm{Cu}$ and 30.3 at $\%$ oxygen is detected at $1150{ }^{\circ} \mathrm{C}$ (Figure $4 \mathrm{~b}$ ). For Fe-deficient spinel ferrites, $\mathrm{Cu}-, \mathrm{Fe}-$, and O-contents of about $30 \mathrm{at} \%, 15 \mathrm{at} \%$, and 50 at $\%$, respectively, were found at low $T_{\mathrm{s}}$. At higher sintering temperatures of $T_{\mathrm{s}} \geq 1050{ }^{\circ} \mathrm{C}$ for $\mathrm{z}=0.02$ and at $T_{\mathrm{s}} \geq 1100^{\circ} \mathrm{C}$ for $\mathrm{z}=0.06$, different elemental concentrations of about 66 at $\% \mathrm{Cu}$, minor quantities of iron, and 30 at $\%$ $\mathrm{O}$ are observed (Figure 4c,d). This indicates a phase transition from tenorite $\mathrm{CuO}$ (theor. 50 at $\% \mathrm{Cu}$ and $\mathrm{O}$ ) to cuprite $\mathrm{Cu}_{2} \mathrm{O}$ (theor. 66 at $\% \mathrm{Cu}$ and 33 at $\% \mathrm{O}$ ) to take place at around $1050{ }^{\circ} \mathrm{C}$ in the $\mathrm{Cu}$-oxide grain boundary phase.

\subsection{Phase Formation}

The phase composition of the ferrites was also investigated using X-ray diffraction (XRD). A single-phase ferrite with spinel-type structure was found at $\mathrm{z}=0$ (not shown here). In the XRD pattern of the sample with $\mathrm{z}=0.06$ (Figure 5), an additional peak at $2 \theta=38.7^{\circ}$, which is identified as (110) reflection of tenorite $\mathrm{CuO}$, appears for samples sintered between $900{ }^{\circ} \mathrm{C}$ and $1100{ }^{\circ} \mathrm{C}$.

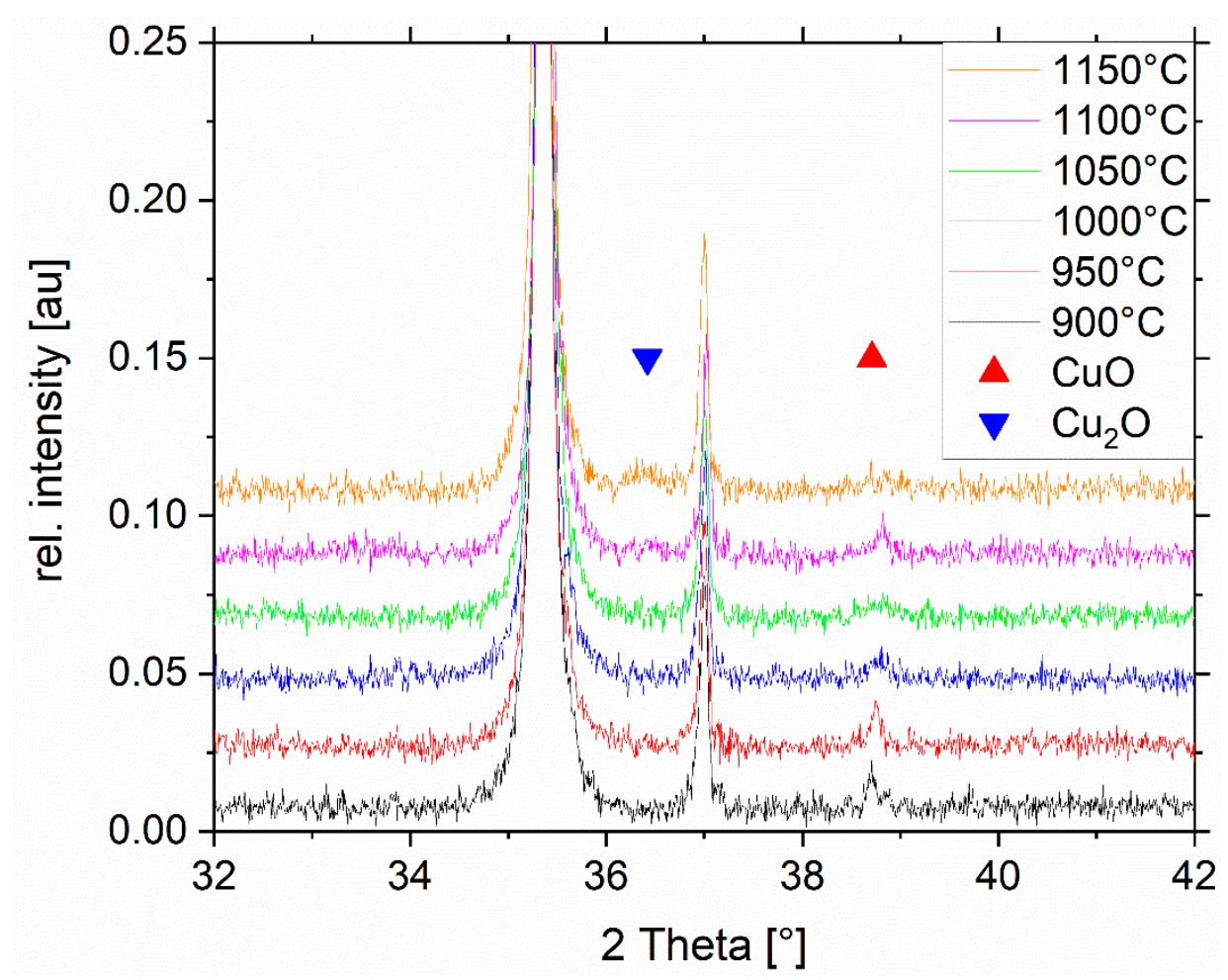

Figure 5. XRD patterns of $\mathrm{z}=0.06$ sintered at temperatures of $900-1150{ }^{\circ} \mathrm{C}$.

This peak was hardly detectable in the ferrite with $\mathrm{z}=0.02$, because, in that case, the $\mathrm{CuO}$ concentration seems to be below the XRD detection limit. For a sample with $\mathrm{z}=0.06$ sintered at $1150{ }^{\circ} \mathrm{C}$, this $\mathrm{CuO}$ peak disappears and another one at about $2 \theta=36.4^{\circ}$ is found, which confirms a phase transition into cuprite $\mathrm{Cu}_{2} \mathrm{O}$ (Figure 5). The cubic lattice 
parameters $a_{0}$ of the spinel ferrites with $\mathrm{z}=0,0.02$, and 0.06 are plotted versus sintering temperature in Figure 6a. An increase of $a_{0}$ with $\mathrm{z}$ reflects a change in the ferrite matrix grain compositions. Moreover, $a_{0}$ also increases somewhat with $T_{\mathrm{s}}$ (for each Fe-deficiency $\mathrm{z}$ ), indicating a very small change in ferrite composition.

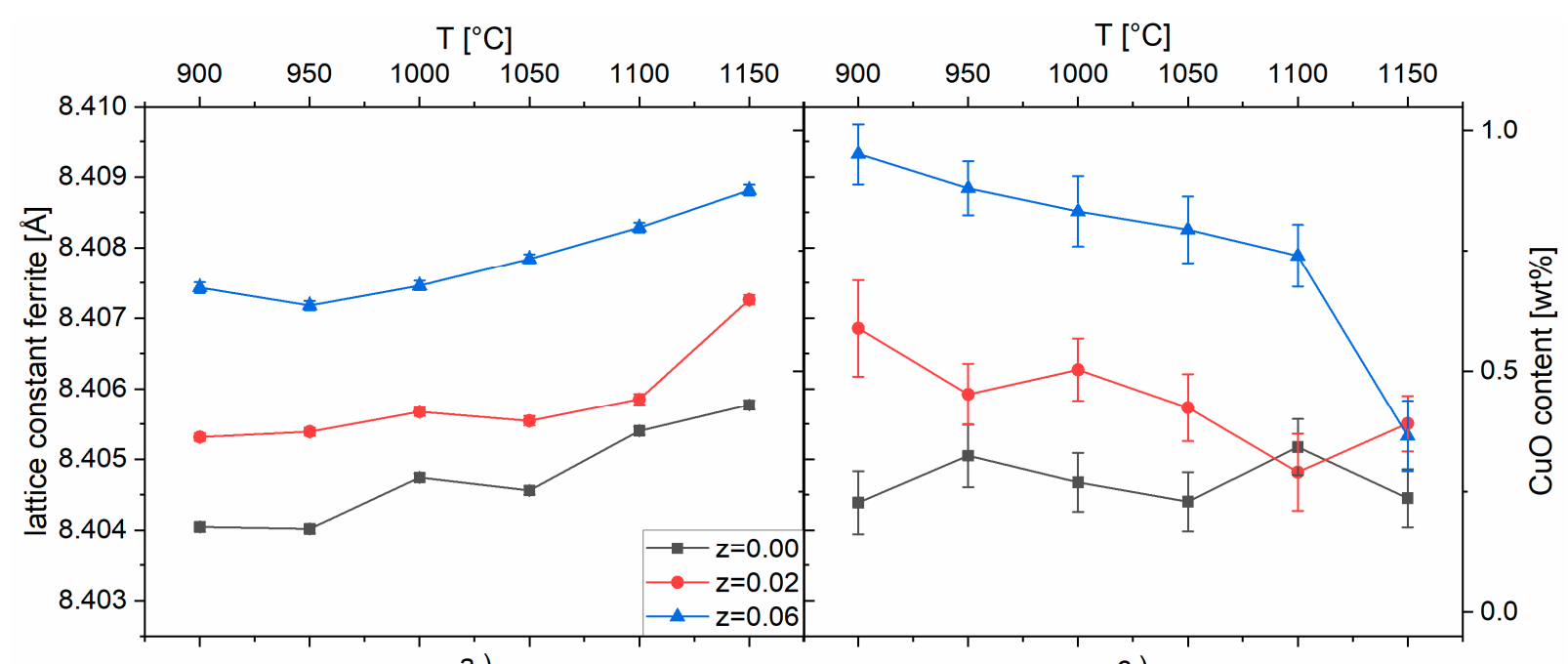

a.)

c.)

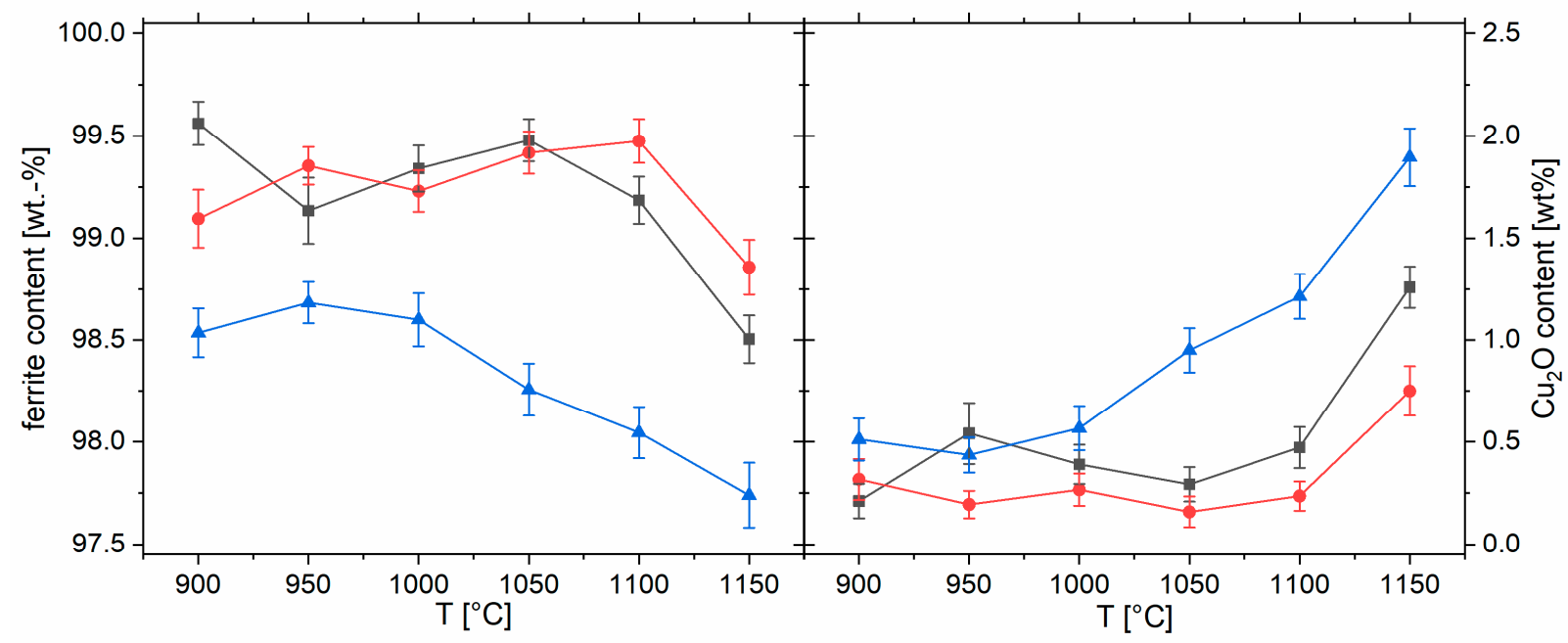

b.)

d.)

Figure 6. (a) Lattice parameters $\mathrm{a}_{0}$, (b) ferrite content, (c) $\mathrm{CuO}$ content, and (d) $\mathrm{Cu}_{2} \mathrm{O}$ content from Rietveld refinements for $0 \leq \mathrm{z} \leq 0.06$ vs. sintering temperature.

The phase compositions of the samples were obtained from Rietveld refinements of XRD powder data. The concentrations of ferrite, tenorite $\mathrm{CuO}$, and cuprite $\mathrm{Cu}_{2} \mathrm{O}$ are shown as a function of sintering temperature $T_{\mathrm{S}}$ in Figure $6 \mathrm{~b}-\mathrm{d}$. For $\mathrm{z}=0$, the ferrite concentration is $>99 \mathrm{wt} \%$, except for the sample sintered at $1150{ }^{\circ} \mathrm{C}$, with slightly reduced ferrite content of about $98.5 \mathrm{wt} \%$. Correspondingly, the $\mathrm{CuO}$ content $(<0.25 \mathrm{wt} \%)$ and the $\mathrm{Cu}_{2} \mathrm{O}$ contents are negligibly small $(<0.5 \mathrm{wt} \%)$ for $T_{\mathrm{s}}=900{ }^{\circ} \mathrm{C}$ to $1100{ }^{\circ} \mathrm{C}$, but the concentration of $\mathrm{Cu}_{2} \mathrm{O}$ increases to $1.25 \mathrm{wt} \%$ at $1150{ }^{\circ} \mathrm{C}$ (Figure $6 \mathrm{~d}$ ). For $\mathrm{z}=0.02$, the ferrite content is also $>99 \mathrm{wt} \%$, except for $T_{\mathrm{s}}=1150{ }^{\circ} \mathrm{C}$, where the ferrite content is $98.7 \mathrm{wt} \%$. The $\mathrm{CuO}$ content is about $0.5 \mathrm{wt} \%$ (Figure $6 \mathrm{c}$ ). The $\mathrm{Cu}_{2} \mathrm{O}$ content is negligibly small at $T_{\mathrm{s}} \leq 1100{ }^{\circ} \mathrm{C}$, but increases to 0.8 wt.- $\%$ at $T_{\mathrm{s}}=1150{ }^{\circ} \mathrm{C}$ (Figure $6 \mathrm{~d}$ ). For larger Fe-deficiency of $\mathrm{z}=0.06$, a clearer situation is observed: the ferrite content (Figure 6b) slightly decreases from $98.5 \mathrm{wt} \%$ at $T_{\mathrm{s}}=900{ }^{\circ} \mathrm{C}$ to $97.7 \mathrm{wt}$.- $\%$ at $T_{\mathrm{s}}=1150{ }^{\circ} \mathrm{C}$. The $\mathrm{CuO}$ concentration (Figure $6 \mathrm{c}$ ) slightly decreases as well from about $0.9 \mathrm{wt} \%$ at $T_{\mathrm{s}}=900{ }^{\circ} \mathrm{C}$ to $0.7 \mathrm{wt} \%$ at $T_{\mathrm{s}}=1100{ }^{\circ} \mathrm{C}$, and then steeply declines 
to $0.35 \mathrm{wt} \%$ at $\mathrm{T}_{\mathrm{s}}=1150{ }^{\circ} \mathrm{C}$. Simultaneously, the cuprite $\mathrm{Cu}_{2} \mathrm{O}$ concentration (Figure $6 \mathrm{~d}$ ) increases with $\mathrm{T}_{\mathrm{s}}$, reaching a maximum of almost $2 \mathrm{wt} \%$ at $T_{\mathrm{s}}=1150{ }^{\circ} \mathrm{C}$.

\subsection{Thermal Analysis}

Thermoanalytical investigations were carried out to characterize the phase transformation behavior (Figure 7). Thermogravimetry (TG) curves of Fe-deficient ferrites with $\mathrm{z}=0.02$ and 0.06 exhibit a slight mass loss at about $1040{ }^{\circ} \mathrm{C}$, indicating a reduction of the $\mathrm{CuO}$ secondary phase and formation of $\mathrm{Cu}_{2} \mathrm{O}$. The stoichiometric ferrite $(\mathrm{z}=0)$ does not show such mass loss in that temperature range, but a small mass loss at $1135{ }^{\circ} \mathrm{C}$, which might signal ferrite decomposition and $\mathrm{Cu}_{2} \mathrm{O}$ formation. For comparison, pure $\mathrm{CuO}$ powder shows a mass loss starting at $1030{ }^{\circ} \mathrm{C}$, indicating reduction and release of oxygen.

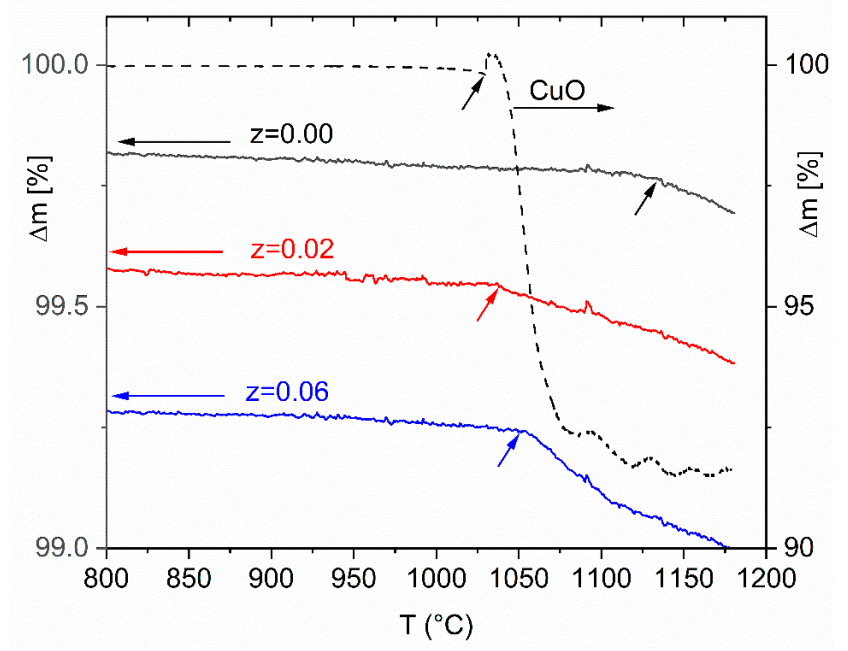

Figure 7. Relative mass losses (TG) for $\mathrm{z}=0.00, \mathrm{z}=0.02, \mathrm{z}=0.06$, and $\mathrm{CuO}$ vs. temperature.

\subsection{Magnetic Permeability}

The complex permeability spectra of two representative samples are shown in Figure 8. A ferrite with $\mathrm{z}=0.06$ sintered at $950{ }^{\circ} \mathrm{C}$ (Figure 8a) with a homogeneous fine-grained microstructure and grain size of $g=2.5(1) \mu \mathrm{m}$ shows a permeability of $\mu^{\prime}=386$ at $1 \mathrm{MHz}$. The imaginary part of permeability $\mu^{\prime \prime}$ has a broad peak centered at $10 \mathrm{MHz}$. A sample of the same composition sintered at $1100{ }^{\circ} \mathrm{C}$ with very large grains has a $\mu^{\prime}=300$ at $1 \mathrm{MHz}$, in combination with a flat and very broad $\mu^{\prime \prime}$ signal (Figure 8b).

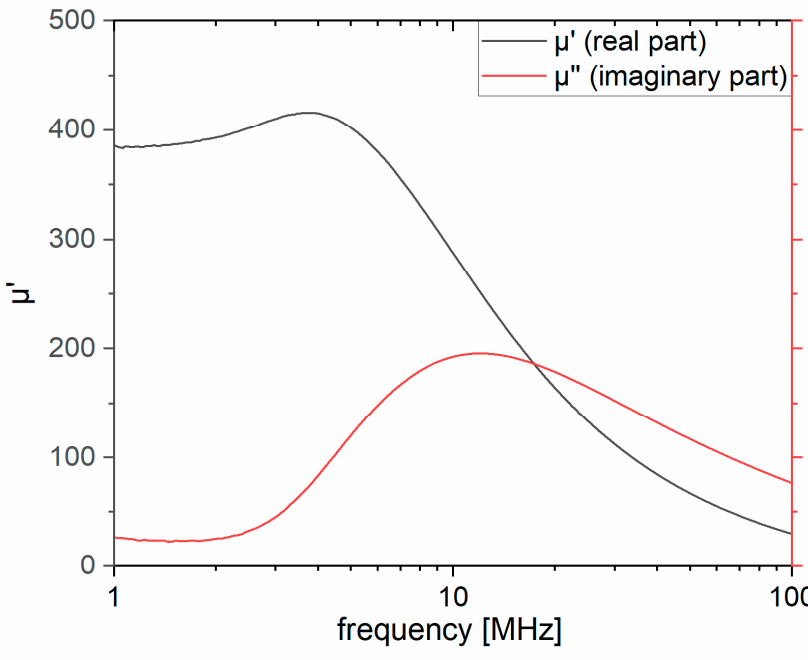

a.)

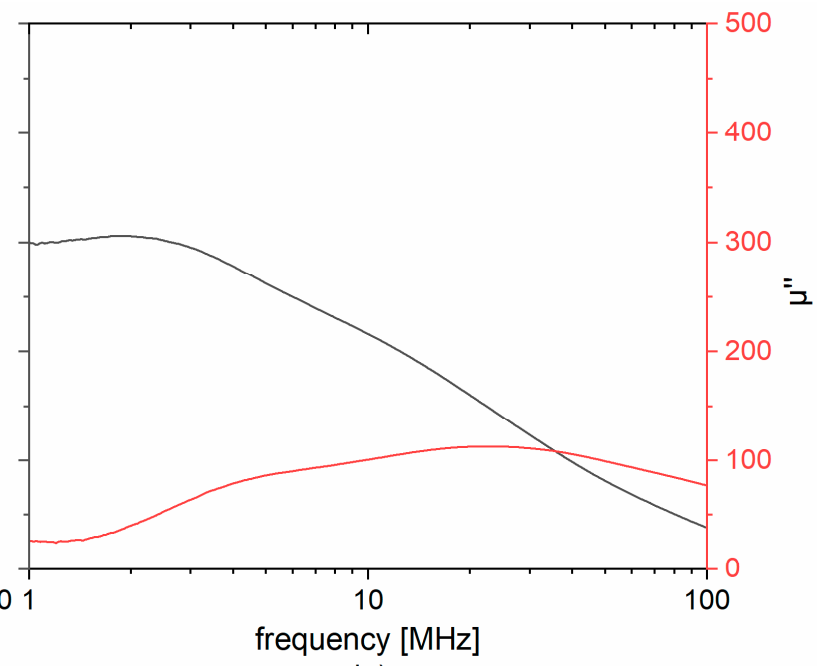

b.)

Figure 8. Permeability spectra vs. frequency for (a) $\mathrm{z}=0.06$ sintered at $950{ }^{\circ} \mathrm{C}$ with fine-grained microstructure and (b) $\mathrm{z}=0.06$ sintered at $1100{ }^{\circ} \mathrm{C}$ with large grains. 
The variation of permeability versus sintering temperature is shown in Figure 9 for all samples. Stoichiometric ferrites $(z=0)$ have the lowest permeability values and the Fedeficient samples with $z=0.02$ show large permeability up to $T_{s}=1000^{\circ} \mathrm{C}$. All three samples series, however, exhibit the same general behavior with a maximum permeability at an intermediate sintering temperature and the permeability decreasing at higher sintering temperatures. This maximum permeability appears at $T_{\mathrm{s}}=1000{ }^{\circ} \mathrm{C}$ for $\mathrm{z}=0(\mu=247)$ and $\mathrm{z}=0.02(\mu=594)$, whereas at $\mathrm{z}=0.06$, a maximum $\mu=437$ is found at $T_{\mathrm{s}}=1050{ }^{\circ} \mathrm{C}$. The variation of permeability versus grain size shows a similar picture (Figure $9 \mathrm{~b})$. The permeability increases with grain size and decreasing inter-crystalline porosity (increasing density) for homogeneous fine-grained microstructures, levels out, and goes through a maximum value of permeability, and finally decreases for samples with microstructures with intra-crystalline porosity and large grains formed by discontinuous grain growth.

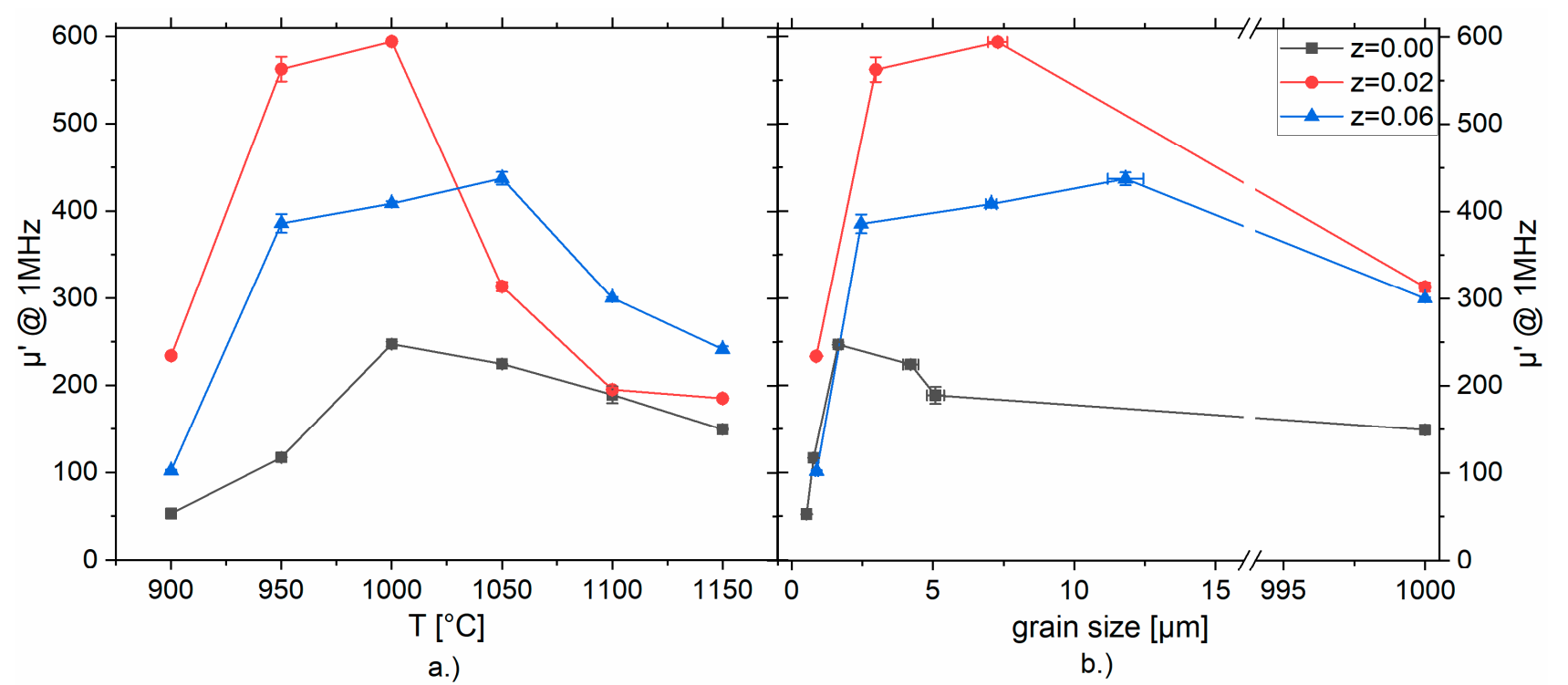

Figure 9. Permeability @ 1MHz (a) vs. sintering temperature and (b) vs. grain size of ferrites with $0 \leq \mathrm{z} \leq 0.06$.

\section{Discussion}

The densification, microstructure, phase composition, and magnetic properties of stoichiometric and Fe-deficient $\mathrm{Ni}-\mathrm{Cu}-\mathrm{Zn}$ ferrites exhibit significant differences. This is documented here for the ferrite series $\mathrm{Ni}_{0.30} \mathrm{Cu}_{0.20} \mathrm{Zn}_{0.50+\mathrm{z}} \mathrm{Fe}_{2-\mathrm{z}} \mathrm{O}_{4-(\mathrm{z} / 2)}$ with Fe-deficiency $0 \leq \mathrm{z} \leq 0.06$. An important advantage of a small Fe-deficiency $(\mathrm{z}=0.02)$ is an enhanced sinter-ability, enabling co-firing with silver metallization at $900{ }^{\circ} \mathrm{C}$ (Figure 1). In a previous study, we have reported similar Fe-deficient Ni-Cu-Zn ferrites sintered at $900{ }^{\circ} \mathrm{C}$ [14]. We observed $\mathrm{CuO}$ as a second phase after sintering at $900{ }^{\circ} \mathrm{C}$ and concluded that the nominally Fe-deficient (sub-stoichiometric) compositions consist of mixture of a Cu-poor stoichiometric ferrite main phase and $\mathrm{CuO}$ as the secondary phase [14]:

$$
\mathrm{Cu}_{\mathrm{y}} \mathrm{Ni}_{1-\mathrm{x}-\mathrm{y}} \mathrm{Zn}_{\mathrm{x}+z} \mathrm{Fe}_{2-\mathrm{z}} \mathrm{O}_{4-\mathrm{z} / 2} \rightarrow\left(\frac{2-\mathrm{z}}{2}\right) \mathrm{Cu}_{\frac{2 \mathrm{y}-3 \mathrm{z}}{2-\mathrm{z}}} \mathrm{Ni}_{\frac{2-2 \mathrm{x}-2 \mathrm{y}}{2-\mathrm{z}}} \mathrm{Zn}_{\frac{2 x+2 z}{2-z}} \mathrm{Fe}_{2} \mathrm{O}_{4}+\frac{3 \mathrm{z}}{2} \mathrm{CuO}
$$

For ferrite compositions reported here ( $\mathrm{y}=0.20$ and $\mathrm{x}=0.50$ ), Equation (1) results in the formation of a spinel $\mathrm{Cu}_{0.17} \mathrm{Ni}_{0.30} \mathrm{Zn}_{0.53} \mathrm{Fe}_{2} \mathrm{O}_{4}$ and $0.03 \mathrm{CuO}$ for an Fe-deficiency of $\mathrm{z}=0.02$, whereas for $\mathrm{z}=0.06$, the ferrite $\mathrm{Cu}_{0.11} \mathrm{Ni}_{0.31} \mathrm{Zn}_{0.58} \mathrm{Fe}_{2} \mathrm{O}_{4}$ coexists with $0.09 \mathrm{CuO}$. The existence of tenorite $\mathrm{CuO}$ is likely to be the reason for the observed shift of shrinkage towards lower temperature (Figure 1a) and the increased density of Fe-deficient ferrites at sintering temperatures between 900 and $1000{ }^{\circ} \mathrm{C}$ (Figure 1b).

In this study, we have extended the range of sintering temperatures. For Fe-deficient ferrites, we observed the coexistence of copper oxide phases for all sintering temperatures. 
This finding is in contrast to the results of other studies: Ni-Cu- $\mathrm{Zn}$ ferrites with irondeficiency between 47 and $50 \mathrm{~mol} \% \mathrm{Fe}_{2} \mathrm{O}_{3}$ (sintered between 1040 and $1200{ }^{\circ} \mathrm{C}$ ) were reported to contain a $\mathrm{ZnO}$ secondary phase [17]. Barba et al. reported a very detailed study on the microstructure and formation of $\mathrm{ZnO}$ and $\mathrm{CuO}$ secondary phases in stoichiometric samples of $\mathrm{Cu}_{0.12} \mathrm{Ni}_{0.23} \mathrm{Zn}_{0.65} \mathrm{Fe}_{2} \mathrm{O}_{4}$ sintered at $1200{ }^{\circ} \mathrm{C}$ and rapidly cooled (quenched or $20 \mathrm{~K} / \mathrm{min}$ cooling rate) [18] or sintered at temperatures between $1000{ }^{\circ} \mathrm{C}$ and $1200{ }^{\circ} \mathrm{C}$ [19] (cooling rate $20 \mathrm{~K} / \mathrm{min}$ ). With a cooling rate of $5 \mathrm{~K} / \mathrm{min}$ used in this study, we did not observe any $\mathrm{ZnO}$ formation in our samples.

Stoichiometric Ni-Cu-Zn ferrite $(\mathrm{z}=0)$ exhibits a homogeneous microstructure, as demonstrated by SEM and EDX (Figure 2), with regular grain growth up to $T_{\mathrm{s}}=1100{ }^{\circ} \mathrm{C}$ (Figure 3), and a single ferrite phase as confirmed by XRD (Figure 6). However, the sample $\mathrm{z}=0$ sintered at $1150{ }^{\circ} \mathrm{C}$ shows the formation of large grains of about $1000 \mu \mathrm{m}$ in size with the precipitation of some $\mathrm{Cu}$ oxide at the grain boundaries (Figure 2), which was identified as $\mathrm{Cu}_{2} \mathrm{O}$ using EDX (Figure $4 \mathrm{~b}$ ). Rietveld refinement of XRD data confirmed the formation of a small, but significant concentration of cuprite $\mathrm{Cu}_{2} \mathrm{O}$ (Figure 6d). Another important feature is the appearance of intra-crystalline porosity in stoichiometric samples sintered at $T_{\mathrm{s}}=1050{ }^{\circ} \mathrm{C}$ and $1100{ }^{\circ} \mathrm{C}$ (Figure 2). For Fe-deficient ferrites with $\mathrm{z}=0.02$ and $\mathrm{z}=0.06$ homogeneous microstructures with regular grain growth are found up to sintering temperatures of $1000{ }^{\circ} \mathrm{C}$ and $1050^{\circ} \mathrm{C}$, respectively (Figure 2). Simultaneously, EDX Cu distribution mappings reflect the formation of $\mathrm{Cu}$-enriched regions at triple points between the ferrite grains. Quantitative EDX analysis revealed the Cu-oxide at the triple points to be tenorite $\mathrm{CuO}$ (Figure $4 \mathrm{c}, \mathrm{d}$ ) with about $24-33$ at $\% \mathrm{Cu}, 18-13$ at $\% \mathrm{Fe}$, and about 50 at $\%$ oxygen for $\mathrm{z}=0.02$ sintered from $900{ }^{\circ} \mathrm{C}$ to $1000{ }^{\circ} \mathrm{C}$ (Figure 4c) and, similarly, with about $24-30$ at $\% \mathrm{Cu}, 18-13$ at $\% \mathrm{Fe}$, and about 50 at $\%$ oxygen for $\mathrm{z}=0.06$ sintered from $T_{\mathrm{s}}=900{ }^{\circ} \mathrm{C}$ to $1050{ }^{\circ} \mathrm{C}$ (Figure $4 \mathrm{~d}$ ). The measured Fe content in the triple point regions might be an artefact of EDX analysis, as part of the measured Fe X-ray intensity might be emitted from surrounding ferrite grains (although the triple point areas are larger than 1-2 $\mu \mathrm{m}$ in diameter). Another interpretation of the simultaneous presence of Fe besides $\mathrm{Cu}$ in triple points is a possible dissolution of iron in the tenorite lattice; the synthesis and properties of $\mathrm{Fe}_{\mathrm{x}} \mathrm{Cu}_{1-\mathrm{x}} \mathrm{O}$ nanoparticles with $\mathrm{x} \leq 0.3$ [21] or $\mathrm{x} \leq 0.125$ [22] were reported recently.

The coexistence of $\mathrm{Cu}$ oxides and ferrites grains was confirmed using XRD (Figure 5). For Fe-deficient samples with $\mathrm{z}=0.06$ a temperature-dependent phase transition of the $\mathrm{Cu}$ oxide secondary phase from tenorite $\mathrm{CuO}$ to cuprite $\mathrm{Cu}_{2} \mathrm{O}$ was confirmed. No indication of zincite $\mathrm{ZnO}$ segregation was found, as discussed above. The slight increase of the cubic ferrite spinel lattice parameter $a_{0}$ versus z (Figure 6a) points to a small change in the ferrite composition with $\mathrm{z}$ (see Equation (1) as discussed above). As increasing $\mathrm{z}$ implies an increase of $\mathrm{Zn}$ content in the ferrite main phase, the observed variation of $a_{0}$ with $\mathrm{z}$ is consistent with the similar trend reported for Ni-Zn ferrites [23]. The results of quantitative Rietveld refinements of the phase compositions shed more light on the variation of the chemistry of the $\mathrm{Cu}$ oxide secondary phase with temperature and $\mathrm{z}$. Whereas the stoichiometric ferrites $(\mathrm{z}=0)$ have no tenorite secondary phase, the $\mathrm{CuO}$ concentration increases from about $0.5 \mathrm{wt} \%$ for $\mathrm{z}=0.02$ to $0.9 \mathrm{wt} \%$ for $\mathrm{z}=0.06$ in the Fe-deficient ferrites (Figure 6c). At higher sintering temperatures, cuprite $\mathrm{Cu}_{2} \mathrm{O}$ is present, with a maximum content of $1.9 \mathrm{wt} \%$ at $T_{\mathrm{s}}=1150{ }^{\circ} \mathrm{C}$ for $\mathrm{z}=0.06$ (Figure $6 \mathrm{~d}$ ). The $\mathrm{Cu}$ oxide phase present at triple points and grain boundaries undergoes a phase transformation:

$$
2 \mathrm{CuO}(s) \rightarrow \mathrm{Cu}_{2} \mathrm{O}(s)+\frac{1}{2} \mathrm{O}_{2}(g)
$$

at $T_{\mathrm{s}}>1050^{\circ} \mathrm{C}$. This is confirmed by thermal analysis (Figure 7). Thermal decomposition of tenorite $\mathrm{CuO}$ starts at $1030{ }^{\circ} \mathrm{C}$ in air. Small mass losses were observed at $1040{ }^{\circ} \mathrm{C}$ and $1050^{\circ} \mathrm{C}$ in the Fe-deficient ferrites with $\mathrm{z}=0.02$ and 0.06 , respectively, (Figure 7), indicating a reduction of the tenorite second phase. With increasing temperature, the remaining $\mathrm{CuO}$ coexists with $\mathrm{Cu}_{2} \mathrm{O}$ and forms a eutectic at $1080^{\circ} \mathrm{C}$ [24], triggering changes in grain growth behavior owing to the presence of a liquid phase. 
The variation of the phase and microstructure formation in Fe-deficient Ni-Cu-Zn ferrites as a function of sintering temperature may be summarized in three consecutive regions:

(I) The ferrites exhibit normal grain growth. Some remaining inter-crystalline porosity is reduced with increasing $T_{\mathrm{s}}$. The stoichiometric ferrite $(\mathrm{z}=0)$ is single-phase spinel, and the Fe-deficient samples $(z>0)$ contain a small amount of tenorite $\mathrm{CuO}$ evenly distributed at the triple points between ferrite grains.

(II) At a critical temperature, for example, at $T_{\mathrm{S}}=1050{ }^{\circ} \mathrm{C}$ for $\mathrm{z}=0, T_{\mathrm{s}}=1000{ }^{\circ} \mathrm{C}$ for $\mathrm{z}=0.02$, and $T_{\mathrm{S}}=1050^{\circ} \mathrm{C}$ for $\mathrm{z}=0.06$, intra-crystalline porosity starts to appear within the ferrite grains. Regular grain growth still dominates.

(III) At a higher sintering temperature, i.e., at $T_{\mathrm{s}}=1150{ }^{\circ} \mathrm{C}$ for $\mathrm{z}=0, T_{\mathrm{s}}=1050{ }^{\circ} \mathrm{C}$ for $\mathrm{z}=0.02$, and $T_{\mathrm{s}}=1100{ }^{\circ} \mathrm{C}$ for $\mathrm{z}=0.06$, a CuO $/ \mathrm{Cu}_{2} \mathrm{O}$ liquid phase appears, forming a network along the grain boundaries and triggering exaggerated growth of the ferrite grains.

The permeability spectra of the ferrites $\mathrm{Ni}_{0.30} \mathrm{Cu}_{0.20} \mathrm{Zn}_{0.50+\mathrm{z}} \mathrm{Fe}_{2-\mathrm{z}} \mathrm{O}_{4-(\mathrm{z} / 2)}(0 \leq \mathrm{z} \leq 0.06)$ reflect the different microstructures of the samples. As an example, a ferrite with $\mathrm{z}=0.06$ sintered at $950{ }^{\circ} \mathrm{C}$ and $1100{ }^{\circ} \mathrm{C}$ shows fine-grained homogeneous or large-grained microstructures, respectively (Figure 2). The permeability of the sample sintered at $950{ }^{\circ} \mathrm{C}$ (Figure $8 \mathrm{a})$ is $\mu^{\prime}=390(1 \mathrm{MHz})$ and starts to decay at $4 \mathrm{MHz}$ with a maximum of $\mu^{\prime \prime}$ at $10 \mathrm{MHz}$. The ferrite sintered at $1100{ }^{\circ} \mathrm{C}$ (Figure $8 \mathrm{~b}$ ) with large grains and porosity within the grains exhibits a reduced permeability of $\mu^{\prime}=300(1 \mathrm{MHz})$ with a gradual decay over the whole frequency spectrum and a corresponding broad $\mu^{\prime \prime}$ peak with its maximum at $30 \mathrm{MHz}$. This is expected because, according to Snoek's law, the shift of the resonance frequency toward higher frequencies is accompanied by a decrease of the absolute values of the permeability.

The intra-crystalline pores in the sample sintered at $1100{ }^{\circ} \mathrm{C}$ act as pinning centers for domains and impede domain wall displacement, and thus reduce the permeability. A similar comparison of two Ni-Cu-Zn ferrites with the same chemistry, but different microstructure was reported by $\mathrm{Su}$ et al. [25].

The variation of permeability (at $1 \mathrm{MHz}$ ) for stochiometric $(z=0)$ and Fe-deficient $(z>0)$ ferrites versus sintering temperature displays a characteristic behavior: the permeability increases at lower sintering temperatures, goes through a maximum, and decreases at high sintering temperatures (Figure 9a). A similar variation of microstructures and permeability with sintering temperature was described for $\mathrm{Ni}_{0.32} \mathrm{Cu}_{0.10} \mathrm{Zn}_{0.58} \mathrm{Fe}_{2} \mathrm{O}_{4}$ by Su et al. [26], and the observed permeability curve of this stoichiometric ferrite was interpreted based on different contributions from domain wall motion and spin rotation magnetization processes. However, as demonstrated in this study, in the case of Fe-deficient $\mathrm{Ni}-\mathrm{Cu}-\mathrm{Zn}$ ferrites, the secondary phase formation and the corresponding microstructures are considered as major factors controlling the permeability of the samples. In region (I) in Fe-deficient ferrites with homogeneous microstructures and small $\mathrm{CuO}$ concentrations, the sample density and grain size increase with $T_{\mathrm{s}}$. Consequently, an increase of permeability is observed as well (Figure 9a). In region (II), intra-crystalline pores tend to hinder domain wall motion and initiate a decrease in permeability. In region (III), however, exaggerate growth of grains with intra-crystalline pores due to the appearance of a liquid phase at high $T_{\mathrm{s}}$ as well as the appearance of a solidified non-magnetic $\mathrm{Cu}$-oxide layer at the grain boundaries during cooling are major factors leading to a continuous reduction of permeability. The increase of permeability of Fe-deficient ferrites as compared with the stoichiometric ferrite at $T_{\mathrm{S}} \leq 1000{ }^{\circ} \mathrm{C}$ is due to higher density; the reduced porosity for $\mathrm{z}=0.02$ enhances domain wall mobility and permeability. For $z>0.02$, on the other hand, the higher amount of segregated, non-magnetic $\mathrm{Cu}$ oxide at triple points and grain boundaries tends to reduce the permeability.

Finally, we discuss the variation of permeability with grain size. The following characteristic features are observed (Figure 9b): the permeability increases with grain size up to a maximum permeability followed by a significant decrease of permeability, which is coupled to the appearance of large grains of about $1 \mathrm{~mm}$ in size separated by grain 
boundaries formed by a solidified $\mathrm{Cu}$ oxide phase. The increase of permeability with grain size in the range of regular grain growth (region I) and levelling of permeability in region (II) is consistent with the non-magnetic grain boundary model [27] assuming the ferrite grains to be surrounded by a non-magnetic grain boundary layer of thickness $\delta$. The effective permeability $\mu_{e}$ scales with the grain size $G$ as follows:

$$
\mu_{e} \frac{\mu_{i} \cdot G}{\mu_{i} \cdot \delta+G}
$$

with $\mu_{i}$ as permeability of the grain interior. For Fe-deficient Ni-Cu-Zn ferrites $(z=0.02$ and 0.06), the formation of non-magnetic tenorite $\mathrm{CuO}$ between ferrite grains promotes densification and grain growth and boosts the permeability in region (I). In region (II), intra-crystalline pores act as domain pinning centers and start to reduce the permeability. Finally, liquid-phase sintered samples with pores in large grains and $\mathrm{Cu}$-oxide layers as grain boundary networks exhibit smaller permeabilities (region III).

\section{Materials and Methods}

Ferrite powders of composition $\mathrm{Ni}_{0.30} \mathrm{Cu}_{0.20} \mathrm{Zn}_{0.50+\mathrm{z}} \mathrm{Fe}_{2-\mathrm{z}} \mathrm{O}_{4-(\mathrm{z} / 2)}$ with $0 \leq \mathrm{z} \leq 0.06$ were prepared by the standard ceramic route. $\alpha-\mathrm{Fe}_{2} \mathrm{O}_{3}$ (Voest Alpine, Linz, Austria, HPG80); NiO (Inco, Black Nickel Oxide, Grade F), CuO (Alpha Aesar, Karlsruhe, Germany), and $\mathrm{ZnO}$ (Harzsiegel, Heubach, Germany, standard grade) were used as starting materials. The oxides were wet mixed for $12 \mathrm{~h}$ in a polyethylene container. After drying, the powder was calcined at $900{ }^{\circ} \mathrm{C}$ for $2 \mathrm{~h}$, and subsequently milled in a planetary ball mill (Fritsch Pulverisette 7; Idar-Oberstein, Germany) in POM grinding beakers for $4 \mathrm{~h}$ (170 rpm) using zirconia grinding media (diameter $1 \mathrm{~mm}$ ). The powders were compacted using polyvinyl alcohol as a binder to produce pellets for sintering studies or toroids for permeability measurements. The samples were sintered for $4 \mathrm{~h}$ at temperatures between $900{ }^{\circ} \mathrm{C}$ and $1150{ }^{\circ} \mathrm{C}$ in air (heating/cooling rate of $5 \mathrm{~K} / \mathrm{min}$ ). The phase formation of the materials was evaluated using X-ray diffraction $(\mathrm{XRD})$ with $\mathrm{Cu}-\mathrm{K}_{\alpha}$ radiation (Bruker AXS, Karlsruhe, Germany, Advance D8). Rietveld refinements were performed using the software Topas version 6 (Bruker AXS). The particle size of the powders was measured using laser diffraction (Malvern Mastersizer 2000, Malvern, UK). The specific surface $S$ of the powders was determined from nitrogen adsorption isotherms (BET, Nova 2000, Quantachrome Instruments, Boynton Beach, FL, USA); a mean particle size $d_{\text {BET }}$ was estimated using the relation $d_{B E T}=6 / \rho \cdot S$ (with density $\rho$; assuming spherical particles). Shrinkage measurements were made with a Netzsch DIL402 (Netzsch, Selb, Germany) dilatometer on cylindrical compacts during heating to $1000{ }^{\circ} \mathrm{C}$ with a $5 \mathrm{~K} / \mathrm{min}$ heating rate. The bulk density of sintered samples was determined using Archimedes' method with heptane as liquid. The microstructure of the samples was studied on polished and thermally etched samples with a scanning electron microscope (SEM, Ultra 55, Zeiss Microscopy GmbH, Jena, Germany). The mean grain size $g_{50}$ was determined using the line intercept method in combination with a factor of 1.57 as proposed by Mendelson [28]. Samples exhibiting exaggerated grain growth were not analyzed using this method and their grain size was generally noted with $1000 \mu \mathrm{m}$. Elemental analysis was performed using a Bruker EDX system on polished and non-etched samples. The permeability of sintered toroids was measured using an Agilent E4991A (St. Clara, CA, USA) impedance/materials analyzer.

\section{Conclusions}

The phase formation, microstructure, und permeability of Fe-deficient $\mathrm{Ni}-\mathrm{Cu}-\mathrm{Zn}$ ferrites $\mathrm{Ni}_{0.30} \mathrm{Cu}_{0.20} \mathrm{Zn}_{0.50+\mathrm{z}} \mathrm{Fe}_{2-\mathrm{z}} \mathrm{O}_{4-(\mathrm{z} / 2)}(0 \leq \mathrm{z} \leq 0.06)$ were investigated as a function of sintering temperature $\mathrm{T}_{\mathrm{s}}$. It is shown that, compared with stoichiometric ferrites $(\mathrm{z}=0)$, Fe-deficient ferrites exhibit specific shrinkage behavior, microstructure, and permeability:

1. With increasing Fe-deficiency $z$, the temperature of the maximum shrinkage rate is shifted from $T=1000{ }^{\circ} \mathrm{C}$ for $\mathrm{z}=0$ towards $T<900{ }^{\circ} \mathrm{C}$ for $\mathrm{z}=0.02$. Firing at $900{ }^{\circ} \mathrm{C}$ gives dense samples for Fe-deficient ferrites $(z>0)$ only. 
2. Stoichiometric ferrites exhibit regular grain growth until, at $1150{ }^{\circ} \mathrm{C}$, exaggerated grain growth sets in owing to the formation of a $\mathrm{Cu}$-oxide liquid phase.

3. Fe-deficient ferrites consist of ferrite grains and a $\mathrm{CuO}$ second phase distributed at the triple points. At sintering temperatures of about $T_{s}>1050^{\circ} \mathrm{C}, \mathrm{CuO}$ is reduced to $\mathrm{Cu}_{2} \mathrm{O}$ and the formation of a eutectic triggers exaggerated ferrite grain growth. These ferrites with large grains exhibit reduced permeability because (i) non-magnetic pores and $\mathrm{Cu}$ oxide grain boundary phases reduce the saturation magnetization and permeability and (ii) pores within ferrite grains and the grain boundary phase act as pinning centers for domain walls, and thus also reduce the permeability.

4. The formation of intra-crystalline porosity sets in already at intermediate sintering temperatures in regularly grown ferrite grains, leading to a reduction in permeability.

5. Sintering protocols of Fe-deficient $\mathrm{Ni}-\mathrm{Cu}-\mathrm{Zn}$ ferrites require optimization of a delicate balance of inter- and intra-crystalline porosity on one hand, and concentration and chemistry of $\mathrm{Cu}$ oxide second phases at triple points and grain boundaries on the other hand, to tailor a maximum permeability performance.

Author Contributions: Conceptualization, C.P. and J.T.; methodology, C.P.; investigation, C.P.; writing—original draft preparation, C.P.; writing—review and editing, J.T.; supervision, J.T.; project administration, J.T.; funding acquisition, J.T. All authors have read and agreed to the published version of the manuscript.

Funding: This work was funded by the Deutsche Forschungsgemeinschaft DFG (Germany) with grant To 165/9-1.

Institutional Review Board Statement: Not applicable.

Informed Consent Statement: Not applicable.

Data Availability Statement: Not applicable.

Conflicts of Interest: The authors declare no conflict of interest.

\section{References}

1. Goldman, A. Handbook of Modern Ferromagnetic Materials, 1st ed.; Kluwer Academic Publishers: Boston, MA, USA; Dordrecht, The Netherlands; London, UK, 1999.

2. Nomura, T.; Nakano, A. New evolution of ferrite for multilayer chip components. In Proceedings of the Sixth International Conference on Ferrites, Tokyo, Japan, 29 September-2 October 1992; pp. 1198-1201.

3. Nakano, A.; Nomura, T. Multilayer Chip Inductors. Ceram. Trans. A Cer. 1999, 97, 285-304.

4. Hsiang, H.I. Progress in materials and processes of multilayer power inductors. J. Mater. Sci. Mater. Electron. 2020, 31, 16089-16110. [CrossRef]

5. Mürbe, J.; Töpfer, J. Ni-Cu-Zn Ferrites for low temperature firing: II. Effects of powder morphology and $\mathrm{Bi}_{2} \mathrm{O}_{3}$ addition on microstructure and permeability. J. Electroceramics 2006, 16, 199-205. [CrossRef]

6. Hsiang, H.I.; Chueh, J.F. $\mathrm{Bi}_{2} \mathrm{O}_{3}$ addition effects on the sintering mechanisms, magnetic properties and DC superposition behavior of NiCuZn ferrites. Int. J. Appl. Ceram. Technol. 2015, 12, 1008-1015. [CrossRef]

7. Su, H.; Zhao, C. Correlation between microstructure and permeability stability of ferrite materials. Ceram. Int. 2018, 44, 2304-2310. [CrossRef]

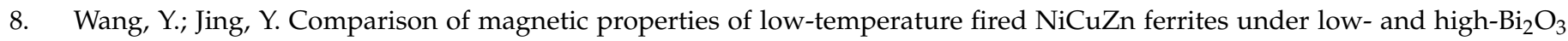
doping modes. J. Electron. Mater. 2020, 49, 3325-3331. [CrossRef]

9. Low, K.O.; Sale, F.R. The development and analysis of property-composition diagrams on gel-derived stoichiometric NiCuZn ferrite. J. Magn. Magn. Mater. 2003, 256, 221-226. [CrossRef]

10. Mürbe, J.; Töpfer, J. Ni-Cu-Zn Ferrites for low temperature firing: I. Ferrite compositions and its effects on sintering behavior and permeability. J. Electroceramics 2005, 15, 215-221. [CrossRef]

11. Zhiyuan, L.; Maoren, X. Effects on iron deficiency on magnetic properties of $\left(\mathrm{Ni}_{0.76} \mathrm{Zn}_{0.24}\right) \mathrm{O}\left(\mathrm{Fe}_{2} \mathrm{O}_{3}\right)_{0.575}$ ferrite. J. Magn. Magn. Mater. 2000, 219, 9-14. [CrossRef]

12. Su, H.; Zhang, H. Effects of composition and sintering temperature on properties of NiZn and NiCuZn ferrites. J. Magn. Magn. Mater. 2007, 310, 17-21. [CrossRef]

13. Su, H.; Tang, X. Influence of Fe-deficiency on electromagnetic properties of low-temperature fired NiCuZn ferrites. J. Magn. Magn. Mater. 2010, 322, 1779-1783. [CrossRef]

14. Mürbe, J.; Töpfer, J. Low temperature sintering of sub-stoichiometric Ni-Cu-Zn ferrites: Shrinkage, microstructure and permeability. J. Magn. Magn. Mater. 2012, 324, 578-583. [CrossRef] 
15. Hsiang, H.I.; $\mathrm{Wu}$, J.L. Copper-rich phase segregation effects on the magnetic properties and DC-bias-superpositions characteristics of NiCuZn ferrites. J. Magn. Magn. Mater. 2015, 374, 367-371. [CrossRef]

16. Sakellari, D.; Tsakaloudi, V. Microstructural phenomena controlling losses in NiCuZn ferrites as studied by transmission electron microscopy. J. Am. Soc. 2008, 91, 366-371. [CrossRef]

17. Sun, K.; Lan, Z. Phase formation, grain growth and magnetic properties of NiCuZn ferrites. J. Magn. Magn. Mater. 2011, 323, 927-932. [CrossRef]

18. Barba, A.; Clausell, C. ZnO and $\mathrm{CuO}$ crystal precipitation in sintering Cu-doped Ni-Zn ferrites. I. Influence of dry relative density and cooling rate. Eur. Ceram. Soc. 2011, 31, 2119-2128. [CrossRef]

19. Barba, A.; Clausell, C. ZnO and $\mathrm{CuO}$ crystal precipitation in sintering $\mathrm{Cu}$-doped Ni-Zn ferrites. II. Influence of sintering temperature and sintering time. Eur. Ceram. Soc. 2017, 37, 169-177. [CrossRef]

20. Nazrin, S.; Sharmin, M. Fabrication and unravelling the impact of iron-deficiency amount on crystal structure, micromorphology, elastic and electromagnetic properties of $\mathrm{Ni}_{0.25} \mathrm{Cu}_{0.13} \mathrm{Zn}_{0.62} \mathrm{Fe}_{2-\mathrm{x}} \mathrm{O}_{4-3 \mathrm{x} / 2}$ ferrites under different sintering conditions. J. Mater. Sci. Mater. Electron. 2021, 32, 4592-4628. [CrossRef]

21. Li, Y.; Xu, M. Structural and room-temperature ferromagnetic properties of Fe-doped CuO nanocrystals. J. Appl. Phys. 2010, 107, 113908. [CrossRef]

22. Nasir, M.; Patra, N. X-ray structural studies on solubility of Fe substituted CuO. RSC Adv. 2016, 6, 103571. [CrossRef]

23. Smit, J.; Wijn, J. Ferrite; Philips Technische Bibliothek: Eindhoven, The Netherlands, 1962.

24. Roberts, H.S.; Hastings Smith, F. The System Copper: Cupric Oxide: Oxygen. J. Am. Chem. Soc. 1921, 43, 1061-1079. [CrossRef]

25. Su, H.; Zhang, H. Effects of microstructure on permeability and power loss characteristics of the NiZn ferrites. J. Magn. Magn. Mater. 2008, 320, 483-485. [CrossRef]

26. Su, H.; Zhang, H. Influence of microstructure on permeability dispersion and power loss of NiZn ferrite. J. Appl. Phys. 2008, 103, 483-485. [CrossRef]

27. Johnson, M.T.; Visser, E.G. A coherent model for the complex permeability in polycrystalline ferrites. IEEE Trans. Magn. 1990, 26, 1987-1989. [CrossRef]

28. Mendelson, M.L. Average grain size in polycrystalline ceramics. J. Am. Ceram. Soc. 1969, 52, 443-446. [CrossRef] 